Inflammation, Vol. 18, No. 4, 1994

\title{
INTRATRACHEAL ADMINISTRATION OF ENDOTOXIN AND CYTOKINES: VIII. LPS Induces E-Selectin Expression; Anti-E-Selectin and Soluble E-Selectin Inhibit Acute Inflammation
}

THOMAS R. ULICH, ${ }^{1}$ SUSAN C. HOWARD ${ }^{2}$

DANIEL G. REMICK, ${ }^{3}$ EUNHEE S. YI, ${ }^{1}$ TUCKER COLLINS, ${ }^{4}$ KAIZHI GUO ${ }^{5}$ SONGMEI YIN, ${ }^{1}$ JEFFERY L. KEENE, ${ }^{2}$ JON J. SCHMUKE, ${ }^{2}$ CHRISTINA N. STEININGER, ${ }^{2}$ JOSEPH K. WELPLY, ${ }^{2}$ and JAMES H. WILLIAMS ${ }^{5}$

${ }^{1}$ Department of Pathology, UC San Diego School of Medicine San Diego, California 92103

${ }^{2}$ Monsanto Corporate Research, Division of Glycosciences Department of Immunology and Infectious Diseases

St. Louis, Missouri 63137

${ }^{3}$ Department of Pathology, University of Michigan School of Medicine Ann Arbor, Michigan 48109

${ }^{4}$ Department of Pathology, Brigham and Women's Hospital

Boston, Massachusetts 02115

${ }^{5}$ Department of Medicine, UC Irvine School of Medicine

Irvine, California 92717

\begin{abstract}
E-selectin is an inducible endothelial adhesion molecule that binds neutrophils. E-selectin mRNA is not constitutively detectable in the lungs of rats. Intratracheal injection of LPS induces pulmonary E-selectin mRNA expression at 2-4 h. Intratracheal injection of LPS followed at 2 and $4 \mathrm{~h}$ by intravenous injection of mouse $\mathrm{F}\left(a b^{\prime}\right)_{2}$ or $\mathrm{F}\left(\mathrm{ab} \mathrm{b}^{\prime}\right)$ anti-E-selectin monoclonal antibody inhibits the emigration of neutrophils into the bronchoalveolar space at $6 \mathrm{~h}$ by $50-70 \%$. TNF and IL-6 bioactivity are not decreased in bronchoalveolar lavage fluid after treatment with anti-E-selectin antibody as compared to controls, suggesting that the anti-E-selectin does not affect the magnitude of the LPS-initiated cytokine cascade. Intratracheal injection of LPS followed at 2 and $4 \mathrm{~h}$ by intravenous injection of soluble E-selectin inhibits neutrophilic emigration at $6 \mathrm{~h}$ by $64 \%$, suggesting that endogenous soluble E-selectin shed from activated endothelium may play a role in the endogenous down-regulation of
\end{abstract}


acute inflammation. E-selectin-mediated adhesion of neutrophils to endothelium appears crucial to the full development of the acute inflammation response.

\section{INTRODUCTION}

The intratracheal injection of endotoxin, a lipopolysaccharide (LPS) component of the cell walls of gram-negative bacteria, up-regulates endogenous interleukin-1 (IL-1) and tumor necrosis factor (TNF) expression in the lung and results in severe local acute inflammation (1). Intratracheal injection of exogenous recombinant IL-1 or TNF also induces acute inflammation in the lung (1). The IL-1 receptor antagonist (2), IL-1 soluble receptor (3), and TNF soluble receptors types I and II $(3,4)$ have been shown to inhibit LPS-induced acute pulmonary inflammation.

E-selectin is an endothelial cell adhesion molecule that is implicated in the intravascular margination of neutrophils at sites of acute inflammation (5). IL-1 and TNF induce E-selectin expression on endothelial cells in vitro $(6,7)$ and in vivo (8) and are therefore postulated to mediate acute inflammation in part via the induction of E-selectin. E-selectin is a member of the selectin glycoprotein lectin family that includes L-selectin and P-selectin (5). The selectin family of membrane proteins is structurally characterized by an extracellular region consisting of a lectin domain adjacent to an epidermal growth factor-like domain followed by six complement regulatory protein-like domains (5). E-selectin binds to sialyl-Lewis $\mathrm{X}$, a constitutively expressed membrane carbohydrate on circulating neutrophils (9). E-selectin expression on pulmonary endothelium has been shown by immunohistochemistry to occur during immune complex-mediated acute lung injury in the rat (10). In the same experimental model, antibody to E-selectin inhibited acute inflammation (10).

The purpose of the present study in rats is to demonstrate: (1) the kinetics of E-selectin expression in the lung after intravenous and intratracheal injection of LPS, (2) inhibition of LPS- and IL-1 initiated acute pulmonary inflammation by intravenous injection of monoclonal antibody to E-selectin, and (3) inhibition of LPS-initiated acute pulmonary inflammation by intravenous injection of soluble E-selectin.

\section{MATERIALS AND METHODS}

Lewis rats, male, weighing approximately $225 \mathrm{~g}$, either naive or at specified time points after the intratracheal injection of $S$. typhosa lipopolysaccharide (Sigma Chemical Co., St. Louis, Missouri), were anesthetized with ether to obtain fresh lung tissue for the extraction of total RNA. While the heart was still beating, the lungs were removed and placed in petri dishes containing 10 
$\mathrm{ml}$ of $4 \mathrm{M}$ guanidium isothiocyanate, $25 \mathrm{mM}$ HEPES ( $\mathrm{pH} 7.0$ ) and $0.7 \mu l \beta$-mercaptoethanol. The lungs, in an ice bath, were immediately homogenized for $30 \mathrm{sec}$ with a Tissuemizer tissue homogenizer. The homogenate was centrifuged in a 50-ml conical tube for $10 \mathrm{~min}$ at $10,000 \mathrm{rpm}$ at $12^{\circ} \mathrm{C}$ in a Beckman JA-13 rotor. The RNA-containing supernatant was collected and Sarkosyl was added to a final concentration of $0.5 \%$. The supernatant was heated at $65^{\circ} \mathrm{C}$ for 2 min and then ultracentrifuged at $25,000 \mathrm{rpm}$ over a CsCl gradient for $20 \mathrm{~h}$ in a Beckman SW-41 rotor. The RNA pellet was resuspended in $10 \mathrm{mM}$ Tris $\mathrm{HCl}(\mathrm{pH} \mathrm{7.4),5} \mathrm{mM} \mathrm{Na}$-EDTA, $1 \%$ SDS at room temperature for 1-2 $\mathrm{h}$, extracted with phenol-chloroform-isoamyl alcohol, and precipitated with $1: 10 \mathrm{vol} 3 \mathrm{M}$ sodium acetate and 2.5 vol absolute ethanol at $-30^{\circ} \mathrm{C}$ overnight. After drying the pellet in a vacuum desiccator, the yield and purity of RNA was quantitated by measuring the ratio of the absorbances at 260 and $280 \mathrm{~nm}$. Successful isolation of undegraded RNA was monitored by mini-gel electrophoresis in the presence of ethidium bromide and examination of the sharpness of the $28 \mathrm{~S}$ and $18 \mathrm{~S}$ ribosomal RNA bands under ultraviolet light. Northern blotting was performed according to standard methodology (11) by electrophoretic separation of total RNA ( $30 \mu \mathrm{g} / \mathrm{lane})$ in a formaldehyde agarose gel followed by blotting of the RNA onto a nylon membrane (Zeta-probe). Rat E-selectin cDNA was used to prepare a probe 1333 nucleotides in length (nucleotides 471-1804 obtained by digestion with Bam HI and Sph I) radiolabeled with $-\alpha^{32} \mathrm{P}$ by random sequence hexanucleotide priming (prime time " $C$ " biosystem, International Biotechnologies, Inc., New Haven, Connecticut) to a specific activity of approximately $10^{9} \mathrm{cpm} / \mu \mathrm{g}$. After hybridization, the blots were washed at $65^{\circ} \mathrm{C}$ for $15 \mathrm{~min}$, twice with $2 \times \mathrm{SSC}$ and $0.1 \%$ SDS and twice with $0.2 \times$ SSC and $0.1 \%$ SDS.

In experiments to assess the potential antiinflammatory activity of anti-E-selectin antibody, male Lewis rats weighing approximately $225 \mathrm{~g}$ were anesthetized with ether and injected intratracheally with $0.5 \mathrm{ml}$ of endotoxin ( $S$. typhus lipopolysaccharide, Sigma) followed at 2 and $4 \mathrm{~h}$ by intravenous injections of either saline, mouse monoclonal $\mathrm{F}\left(\mathrm{ab}^{\prime}\right)_{2}^{\prime}$ or $\mathrm{F}\left(\mathrm{ab}^{\prime}\right)$ anti-human E-selectin (clones M4 or A3), or mouse monoclonal $\mathrm{F}\left(\mathrm{ab}^{\prime}\right)_{2}^{\prime}$ anti-plant sucrose phosphate synthetase (clone HH8). Hybridomas producing monoclonal antibodies (clones M4, A3, and HH8) were kindly provided by Chris Carron, Debbic Meyer, and Jodi Pegg (Monsanto Cellular and Molecular Biology). For anti-E-selectin antibodies, mice were immunized with activated human umbilical vein endothelial cells and screened using a purified recombinant E-selectin. Monoclonal antibodies were purified from ascites fiuid by caprylic acid precipitation followed by ammonium sulfate precipitation according to the method of Reik et al. (12). $\mathrm{F}\left(\mathrm{ab}^{\prime}\right)_{2}$ fragments were prepared from mouse ascites fluid by digesting purified immunoglobulins overnight with activated papain in $0.1 \mathrm{M}$ sodium acet ice, pH 5.5, $3 \mathrm{mM}$ EDTA, using a 20:1 ratio of monoclonal antibody to enzyme, according to the method of Parham et al. (13). The reaction was stopped by the addition of $30 \mathrm{mM}$ iodoacetamide. For $\mathrm{F}\left(\mathrm{ab}^{\prime}\right)$ production, a low level of cysteine (approximately $10 \mathrm{mM}$ ) was present during digestion. The digest $(<100 \mathrm{mg})$ was chromatographed over a $3-\mathrm{ml}$ bed volume DEAE-cellulose column, equilibrated in $5 \mathrm{mM}$ Tris $\mathrm{HCl}, \mathrm{pH} \mathrm{7.5,} \mathrm{to} \mathrm{remove} \mathrm{the} \mathrm{Fc}$ fragments, followed by a 3-ml bed volume protein A sepharose column equilibrated in the same buffer in order to remove any remaining intact IgG1, followed by chromatography over a $2.5-\mathrm{cm} \times 46-\mathrm{cm}$ Sephadex G-75 sizing column equilibrated in Dulbecco's phosphate-buffered saline without divalent cations (Sigma) in order to separate the $F\left(a^{\prime}\right)_{2}$ from other reaction products. The final column for resolution of $F\left(a b^{\prime}\right)_{2}$ and $F\left(a^{\prime}\right)$ was a Sephadex G-150 column, $2.5 \times 48 \mathrm{~cm}$.

Soluble recombinant human monomeric E-selectin was prepared by papain digestion to remove the $\mathrm{Fc}$ portion of a dimeric E-selectin- $\mathrm{Fc}$ fusion protein. Recombinant baby hamster kidney (BHK) cells producing a chimeric human E-selectin- $\operatorname{IgG}_{1} \mathrm{Fc}$ molecule was kindly provided by Lyle $\mathrm{E}$. Pegg (Monsanto Cellular and Molecular Biology). The gene, a generous gift of Brian Seed (Massachusetts General Hospital, Boston, Massachusetts) had been expressed in BHK cells using the herpesvirus VP16 transactivator [P. Hippenmeyer, M. Highkin. High-level stable production of recombinant proteins in mammalian cell culture using the herpesvirus VP16 transactivator. Biotechnology, 11:1037-1041, 1993]. The recombinant protein was batch adsorbed onto A3 sepharose 
and eluted in column mode with $3 \mathrm{M} \mathrm{MgCl}_{2}, 0.5 \mathrm{M} \mathrm{NaCl}, \mathrm{pH} 6.8$. Following dialysis into $0.9 \%$ $\mathrm{NaCl}, 25 \mathrm{mM} \mathrm{CaCl}$, the fusion protein was digested with activated papain using a substrate-toenzyme ratio of $70: 1$. The reaction was stopped by the addition of $30 \mathrm{mM}$ iodoaceamide, and monomeric E-selectin was purified by chromatography over the protein A sepharose and Sephadex G-150 sizing columns as described above for the purification of $F(a b)^{\prime}$ fragments.

Six hours after injection of intratracheal LPS and intravenous antibodies or soluble E-selectin, the rats were sacrificed and bronchoalveolar lavage (BAL) was performed to enumerate the absolute number of neutrophils in the intraalveolar inflammatory exudate as previously described (1). The absolute number of neutrophils in the BAL fluid specimens is expressed as the mean \pm one standard deviation of the mean. TNF and IL-6 protein levels in BAL fluid specimens were determined as previously described (WEHI 164, subclone 13 bioassay for TNF, B9 bioassay for IL-6) (14). The probability value was determined by the $t$ test (Systat, Inc. Evanston, Illinois).

\section{RESULTS}

E-selectin mRNA is not constitutively detected in the lung (Figure 1). Intratracheal injection of LPS $(100 \mu \mathrm{g})$ causes E-selectin mRNA expression at 4 and $6 \mathrm{~h}$ (Figure 1). Intravenous injection of LPS $(100 \mu \mathrm{g})$ causes E-selectin mRNA expression at $2 \mathrm{~h}$ (Figure 1). E-selectin mRNA expression is no longer detected at $4 \mathrm{~h}$ after intravenous injection of LPS (Figure 1).

Monoclonal $\mathrm{F}\left(\mathrm{ab}^{\prime}\right)_{2}$ anti-E-selectin antibody clones $\mathrm{A} 3$ and M4, injected

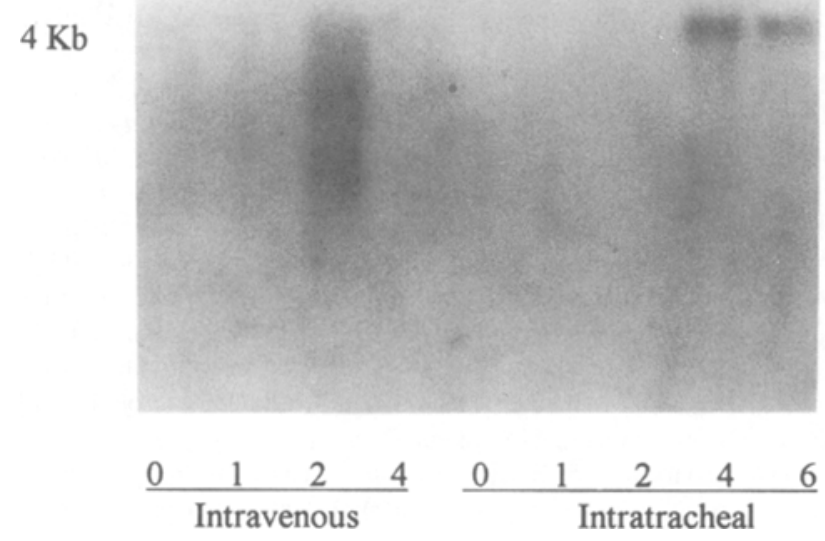

E-Selectin

\section{Hours after Injection of LPS (100 ug)}

Fig. 1. Intravenous injection of LPS $(100 \mu \mathrm{g})$ causes the rapid and transient expression of pulmonary E-selectin mRNA at $2 \mathrm{~h}$. Intratracheal injection of LPS $(100 \mu \mathrm{g})$ causes a later and more sustained expression of pulmonary E-selectin mRNA at 4 and $6 \mathrm{~h}$. 
intravenously at 2 and $4 \mathrm{~h}\left(500 \mu \mathrm{g} \mathrm{F}\left(\mathrm{ab}^{\prime}\right)_{2}\right.$ at 2 and $\left.4 \mathrm{~h}\right)$ after intratracheal injection of $5 \mu \mathrm{g}$ LPS, both significantly inhibit the emigration of neutrophils into BAL fluid at $6 \mathrm{~h}$ by more than $50 \%$ (Table 1$)$. A higher dose of M4 (1 mg $\mathrm{F}\left(\mathrm{ab}^{\prime}\right)_{2}$ at 2 and $\left.4 \mathrm{~h}\right)$ did not afford further inhibition of inflammation $(N=6$ rats with the higher dose of M4 and $N=6$ controls, data not shown). The number of neutrophils in BAL fluid is not decreased by intravenous injection of an unrelated monoclonal antibody of the same species and IgG class (HH8) or by bovine serum albumin (BSA) (Table 1). $F\left(a b^{\prime}\right)$ fragments of anti-E-selectin clone M4 were as effective as $\mathrm{F}\left(\mathrm{ab}^{\prime}\right)_{2}$ fragments in inhibiting inflammation (Table 1). Intratracheal coinjection of LPS and $F\left(a^{\prime}\right)$ anti-E-selectin clone M4 did not significantly inhibit inflammation (data not shown). Intratracheal injection of IL-1 $\beta(5 \mu \mathrm{g})$ followed by intravenous injection of anti-E-selectin clone M4 (500 $\mu \mathrm{g} \mathrm{F}\left(\mathrm{ab}^{\prime}\right)_{2}$ at 2 and $\left.4 \mathrm{~h}\right)$ significantly inhibits IL-1-induced acute inflammation (Table 2).

Table 1. Intravenous Injection of Anti-E-Selectin Antibody Clones A3 or M4 Inhibits Acute Inflammation Induced by Intratracheal Injection of LPS

\begin{tabular}{|c|c|c|c|c|}
\hline Injection protocol ${ }^{a}$ & $N$ & $\mathrm{PMN} \times 10^{6} \mathrm{BAL}$ & $\begin{array}{c}\text { Inhibition } \\
(\%)\end{array}$ & $P$-value \\
\hline \multicolumn{5}{|l|}{ E-Selectin neutralizing antibodies } \\
\hline LPS IT + saline IV & 9 & $10.2 \pm 1.6$ & & \\
\hline LPS IT $+A 3 F\left(a b^{\prime}\right)_{2}$ IV & 8 & $5.0+0.7$ & 51 & $<0.001$ \\
\hline LPS IT + saline IV & 6 & $9.4 \pm 0.6$ & & \\
\hline LPS IT + M4 F(ab' $)_{2}$ IV & 6 & $3.2 \pm 0.9$ & 66 & $<0.001$ \\
\hline LPS IT + saline IV & 6 & $9.4 \pm 0.5$ & & \\
\hline LPS IT + M4 F(ab') IV & 6 & $2.9 \pm 0.8$ & 69 & $<0.001$ \\
\hline \multicolumn{5}{|l|}{ Negative Controls } \\
\hline LPS IT + saline IV & 6 & $11.1 \pm 2.7$ & & \\
\hline LPS IT + HH8 F(ab') $)_{2}$ IV & 6 & $11.0 \pm 2.3$ & 0 & NS \\
\hline LPS IT + saline IV & 6 & $9.4 \pm 0.3$ & & \\
\hline LPS IT + BSA IV & 6 & $8.9 \pm 1.1$ & 5 & NS \\
\hline
\end{tabular}

${ }^{a} \mathrm{IT}=$ intratracheal; IV = intravenous.

Table 2. Intravenous Injection of Anti-E-Selectin Antibody Inhibits Acute Inflammation Induced by Intratracheal Injection of IL-1

\begin{tabular}{lcccc}
\hline \multicolumn{1}{c}{ Injection protocol } & $N$ & PMN $\times 10^{6} / \mathrm{BAL}$ & $\begin{array}{c}\text { Inhibition } \\
(\%)\end{array}$ & $P$ value \\
\hline IL-1 IT + saline IV & 6 & $13.0 \pm 2.9$ & & \\
IL-1 IT $+\mathrm{M} 4 \mathrm{~F}\left(\mathrm{ab}^{\prime}\right)_{2}$ IV & 6 & $4.6 \pm 1.0$ & 64 & $<0.001$ \\
\hline
\end{tabular}


Table 3. Intravenous Injection of Anti-E-Selectin Antibody Does Not Alter TNF and IL-6 Activity in BAL Fluid after Intratracheal Injection of LPS

\begin{tabular}{llcc}
\hline \multicolumn{1}{c}{ Injection protocol } & $N$ & TNF $(\mathrm{pg} / \mathrm{ml})$ & IL-6 $(\mathrm{pg} / \mathrm{ml})$ \\
\hline Saline IT + saline IV & 2 & $<5$ & $<5$ \\
LPS IT + saline IV & 9 & $181 \pm 115$ & $2891 \pm 1013$ \\
LPS IT + A3 IV & 8 & $228 \pm 78$ & $3000 \pm 546$ \\
\hline
\end{tabular}

Table 4. Intravenous Injection of Soluble E-Selectin Inhibits Acute Inflammation Induced by Intratracheal Injection of LPS

\begin{tabular}{lcccr}
\hline \multicolumn{1}{c}{ Injection protocol } & $N$ & PMN $\times 10^{6} / \mathrm{BAL}$ & $\begin{array}{c}\text { Inhibition } \\
(\%)\end{array}$ & $P$ value \\
\hline LPS IT + saline IV & 6 & $11.6 \pm 2.7$ & & \\
LPS IT + soluble E-selectin IV & 6 & $4.2 \pm 1.0$ & 64 & $<0.001$ \\
\hline
\end{tabular}

Intratracheal LPS-induced TNF and IL-6 bioactivity in BAL fluid are not affected by intravenous injection of antibody to E-selectin (Table 3).

Soluble E-selectin injected intravenously ( $500 \mu \mathrm{g}$ soluble E-selectin at 2 and $4 \mathrm{~h}$ ) after intratracheal injection of $5 \mu \mathrm{g}$ LPS significantly inhibits the emigration of neutrophils into BAL fluid at $6 \mathrm{~h}$ by $64 \%$ (Table 4 ).

\section{DISCUSSION}

The kinetics of neutrophil influx into the lung are different after intravenous and intratracheal injection of LPS. After intravenous injection of $100 \mu \mathrm{g}$ of LPS, neutrophils are rapidly sequestered intravascularly in the lung but do not emigrate into the bronchoalveolar space. After intratracheal injection of $100 \mu \mathrm{g}$ LPS, neutrophils emigrate into the bronchoalveolar space at 2-4 h.

The kinetics of E-selectin mRNA expression in the lung are also different after intravenous and intratracheal injection of LPS. E-selectin expression after intravenous injection of LPS occurs earlier and more transiently than after intratracheal injection. In the case of intravenous injection of LPS, endothelial cells may be postulated to express E-selectin via the action of circulating IL-1 and TNF, whose serum concentrations are known to be sharply elevated at 1-2 h after intravenous injection of LPS. The expression of E-selectin at $2 \mathrm{~h}$ after intravenous injection of LPS is consistent with the kinetics of intravascular neutrophil sequestration within the lung $(15,16)$. The possibility can also be 
considered that circulating LPS may directly bind to endothelial cells to stimulate E-selectin expression. E-selectin expression occurs at 4-6 h after intratracheal injection of LPS and may be postulated to be the result of alveolar macrophagederived IL-1 and TNF.

Finally, the different kinetics of E-selectin mRNA expression in the lung after intravenous and intratracheal injection of LPS are consistent with the different expression of IL-1 and TNF after intravenous and intratracheal injection of LPS. In contrast to the rapid and transient nature of IL-1 and TNF expression in serum after intravenous injection of LPS $(17,18)$, IL-1 and TNF expression in the lung and BAL fluid increase 4-6 after intratracheal injection of LPS (1). The differing kinetics of IL-1, TNF, and E-selectin expression in the lung after intravenous and intratracheal injection of LPS thus correlate well with the differences in the kinetics and anatomic localization of neutrophils in the lung.

Intratracheal injection of LPS or IL- $1 \beta$ followed by intravenous injection of two different clones of anti-E-selectin significantly inhibited the emigration of neutrophils into BAL fluid by greater than $50 \%$. Antibody to E-selectin was injected intravenously to allow greater access of the antibody to E-selectin expressed on the vascular surface of endothelial cells. Both $F\left(a b^{\prime}\right)_{2}$ and $F\left(a b^{\prime}\right)$ fragments of anti-E-selectin antibody were able to inhibit acute inflammation equally effectively. Intratracheal coinjection of LPS and F(ab') anti-E-selectin antibody did not inhibit inflammation, a result that may be due to the timing of the injection and/or lack of access of the intratracheal injected antibody to the vascular surface of endothelial cells expressing $E$-selectin. $F\left(a^{\prime}\right)$ antibody was chosen for intratracheal injection on the assumption that the smaller size of the $F\left(a b^{\prime}\right)$ fragments would allow for greater diffusion of the antibody from the local tissue compartment into the vascular space. Intratracheal injection of antibody at 2 and $4 \mathrm{~h}$ after intratracheal injection of LPS was not attempted because of the technical difficulty of the procedure.

The observation that TNF and IL- 6 bioactivity in BAL fluid are not affected by intravenous injection of antibody to E-selectin is of note not only as a confirmation that the LPS-initiated cytokine cascade was equivalent in the experimental and control groups, but also as an indication that the TNF and IL-6 activity in the BAL fluid may be largely alveolar macrophage-derived as opposed to neutrophil-derived. Since the neutrophil number in the BAL fluid of rats receiving anti-E-selectin was decreased by more than $50 \%$, a decrease in TNF and IL-6 activity would have been expected if neutrophils contributed substantially to TNF and IL-6 expression. Neutrophils are described to express many cytokines including TNF, IL-1, and IL-6 (19-21). In previous experiments from our laboratory in which intratracheal LPS-initiated inflammation was inhibited by blockade of IL-1 and TNF (2-4), a dissection of the contributions of neutrophils and alveolar macrophages to TNF and IL-6 expression was not possible. Soluble E-selectin is present in the circulation of patients with septic shock 
(22). The experimental observation that recombinant circulating E-selectin can suppress acute inflammation suggests that endogenous circulating E-selectin may play a role in the endogenous down-regulation of acute inflammation. As endothelial-bound E-selectin is shed into the circulation during the course of an acute inflammatory reaction, a time must exist when some E-selectin in endothelialbound and some is circulating. The ratio of endothelial-bound to circulating E-selectin presumably decreases with time. The intravenous administration of antibody to E-selectin or of E-selectin antagonists would likely result in inactivation of both endothelial-bound and circulating E-selectin. Whether any differences in binding rate to endothelial-bound or circulating E-selectin might exist is unclear. One can hypothesize that a time point during the inflammatory reaction exists when more endogenous E-selectin is present in the circulation than on endothelial cells. The administration of anti-E-selectin at that time point might interfere more with an endogenous mechanism for the down regulation of inflammation than with the proinflammatory function of E-selectin. The pharmacologic use of anti-E-selectin as an antiinflammatory agent at such a time point during the clinical course of an inflammatory disease might even produce the undesirable result of aggravating inflammation. On the other hand, the pharmacologic use of soluble E-selectin to block neutrophil-bound E-selectin ligand would not be complicated by the presence of endogenous circulating E-selectin.

In conclusion, LPS-initiated release of macrophage-derived IL-1 and TNF would appear to induce endothelial cell E-selectin expression to contribute to the accumulation of neutrophils during acute inflammation. Antibodies to endothelial-bound E-selectin as well as soluble E-selectin may prove beneficial for the treatment of inflammation by interfering with the margination of neutrophils to endothelium at sites of acute inflammation.

Acknowledgments - The authors wish to thank Charles Lewis, Roger Monsell, and Rich Wolfe for large-scale cell culture of the A3 hybridoma and the E-selectin-Fc recombinant BHK cells.

\section{REFERENCES}

1. Ulich, T. R., L. R. Watson, S. Yin, K. Guo, P. Wang, H. Thang, and J. del Castillo. 1991. The intratracheal administration of endotoxin and cytokines. I. Characterization of LPSinduced IL- 1 and TNF mRNA expression and the LPS-, IL-1-, and TNF-induced inflammatory infiltrate. Am. J. Pathol. 138:1485-1496.

2. Ulich, T. R., S. Yin, K. Guo, J. del Castillo, S. P. Eisenberg, and R. C. Thompson. 1991. The intratracheal administration of endotoxin and cytokines. III. The interleukin-1 receptor antagonist inhibits endotoxin- and IL-1-induced acute inflammation. Am. J. Pathol. 138:521524.

3. Ulich, T. R., S. E. Yi, S. YIN, C. SMIth, and D. REMick. 1994. Intratracheal administration of endotoxin and cytokines: VII. The soluble interleukin-1 receptor and the soluble tumor 
necrosis factor receptor II (p80) inhibit acute inflammation. Clin. Immunol. Immunopathol. (in press).

4. Ulich, T.R., S. Yin, D. G. Remick, D. Russell, S. P. Eisenberg, and T. Kohno. 1993. Intratracheal administration of endotoxin and cytokines. IV. The soluble TNF receptor type I inhibits acute inflammation. Am. J. Pathol. 142;1335-1338.

5. Bevillacqua, M. P., S. Stengelin, M. A. Gimbrone, and B. Seed. 1989. Endothelial leukocyte adhesion molecule 1: An inducible receptor for neutrophils related to complement regulatory proteins and lectins. Science 243:1160-1165.

6. Bevillacqua, M. P., J. S. Pober, D. L. Mendrick, R. S. Cotran, and M. A. Gimbrone. 1987. Identification of an inducible endothelial leukocyte adhesion molecule. Proc. Natl. Acad. Sci. U.S.A. 84:9238-9242.

7. Munro, J. M., J. S. Pober, and R. S. Cotran. 1989. Tumor necrosis factor and interferon gamma induced distinct patterns of endothelial activation and associated leukocyte accumulation in the skin of Papio anubis. Am. J. Pathol. 135:121-133.

8. Munro, J. M., J. S. Pober, and R. S. Cotran, 1991. Recruitment of neutrophils in the local endotoxin response: Association with de novo endothelial expression of endothelial leukocyte adhesion molecule 1. Lab. Invest. 64:295-299.

9. Munro, M., S. K. Lo, C. Corless, M. Robertson, N. C. Lee, R. L. Barnhill, D. S. WeinberG, and M. BevilacQua. 1992. Expression of sialyl Lewis X, an E-selectin ligand, in inflammation, immune process, and lymphoid tissues. Am. J. Pathol. 141:1397-1408.

10. Mulligan, M. S., J. Varani, M. K. Dame, C. L. Lane, C. W. Smith, D. Anderson, and P. WARD. 1991. Role of endothelial leukocyte adhesion molecule 1 (ELAM-1) in neutrophilmediated lung injury in rats. J. Clin. Invest. 88:1396-1406.

11. Wahl, G. M., J. L. Meinkoth, and A. R. Kimmel. 1987. Northern and Southern blots. In Guide to Molecular Cloning Techniques. Edited by S. L. Bergen and A. R. Kimmel, editors. Academic Press, New York, p 572.

12. Reik, L. M., S. L. Maines, D. E. Ryan, W. Levin, S. Bandiera, and P. E. Thomas. 1987. A simple nonchromatographic purification procedure for monoclonal antibodies. J. Immunol. Methods 100:123-130.

13. Parham, P., M. J. Androlewicz, F. M. Brodsky, N. J. Holmes, and J. P. Ways. 1982. Monoclonal antibodies: Purification, fragmentation, and application to structural and functional studies of class I MHC antigens. J. Immunol. Methods 53:133-173.

14. Ulich, T. R., J. del Castillo, D. Remick, K. Guo, S. Yin, and P. Weng. 1991. Endotoxininduced cytokine gene expression in vivo III: Interleukin- 6 mRNA and serum protein expression and the in vivo hematologic effects of IL-6. J. Immunol. 146:2316-2323.

15. Williams, J. H., S. Patel, D. Hatekayama, R. Arian, K. Guo, T. Hickey, S. Y. Liao, and T. R. ULICH. 1993. Activated pulmonary vascular neutrophils as early mediators of endotoxin-induced lung inflammation. Am. J. Respir. Cell. Mol. Biol. 8:134-144.

16. Chang, J. C., and M. Lessor, 1984. Quantitation of leukocytes in bronchoalveolar lavage samples from rats after intravascular injection of endotoxin. Am. Rev. Respir. Dis. 129:72-75.

17. Ulich, T. R., K. Guo, B. IRwin, D. G. Remick, and G. N. Davatelis. 1990. Endotoxininduced cytokine gene expression in vivo II. Regulation of TNF and IL-1 expression and suppression. Am. J. Pathol. 137:1137.

18. WAAGE, A. 1987. Production and clearance of tumor necrosis factor in rats exposed to endotoxin and dexamethasone. Clin. Immunol. Immunopathol. 45:348.

19. Dubravec, D. B., D. R. Spriggs, J. A. Mannick, and M. L. Rodrick. 1990. Circulating human peripheral blood granulocytes synthesize and secrete tumor necrosis factor $\alpha$. Proc. Natl. Acad. Sci. U.S.A. 87:6758-6761.

20. Cicco, N. A., A. Lindemann, J. Content, P. Vandenbusssche, M. Lubbert, J. Gauss, R. 
MERTELSMANN, and F. HERMAN. 1990. Inducible production of IL-6 by human polymorphonuclear neutrophils. Blood 75:2049.

21. LoRd, P. C. W., L. G. M. Wilmoth, S. B. Mizel, and C. E. McCall. 1991. Expression of IL- $1 \alpha$ and $\beta$ genes by human blood polymorphonuclear leukocytes. J. Clin. Invest. 87:13121321.

22. Newman, W., L. D. Beall, C. W. Carson, G. G. Hunder, N. Graben, Z. A. Randhawa, T. V. Gopal, J. Wiener-Kronish, and M. A. Matthay. 1993. Soluble E-selectin is found in supernatants of activated endothelial cells and is elevated in serum of patients with septic shock. J. Immunol. 150:644-654. 